\title{
Konsentrasi Logam Pb Di Enhalus acoroides LF. Royle 1839 (Angiosperms : Hydrocharitaceae) dan Lingkungannya di Perairan Kartini Dan Teluk Awur, Jepara
}

\author{
Betta Rianda*, Ria Azizah Tri Nuraini, Sunaryo \\ Departemen IImu Kelautan, Fakultas Perikanan dan IImu Kelautan, Universitas Diponegoro \\ JI. Prof. H. Soedarto S.H, Tembalang,Semarang, Jawa Tengah 50275 Indonesia \\ ${ }^{*}$ Corresponding author, e-mail: bettarianda@gmail.com
}

\begin{abstract}
ABSTRAK : Lamun jenis Enhalus acoroides merupakan salah satu komponen keanekaragaman hayati yang tumbuh di Perairan Kartini dan Teluk Awur. Aktivitas pariwisata, pelabuhan, pembuatan, pengecatan, pengelasan, pembersihan dan lalu lintas kapal nelayan menjadi penyebab terakumulasinya logam berat di perairan. Logam berat $\mathrm{Pb}$ merupakan logam berat beracun dan berbahaya, bahan pencemar dan cenderung mengganggu kelangsungan hidup organisme perairan. Tujuan penelitian ini ialah mengetahui dan menganalisis kandungan logam berat $\mathrm{Pb}$ pada air, sedimen dan lamun Enhalus acoroides (akar dan daun) di Perairan Kartini dan Teluk Awur, Jepara, serta mengetahui tingkat pecemarannya berdasarkan baku mutu. Penelitian ini menggunakan metode deskriptif, sedangkan metode penentuan lokasi menggunakan metode purposive sampling. Hasil penelitian menunjukkan kandungan logam berat $\mathrm{Pb}$ air di Perairan Kartini sebesar 0,181-0,316 mg/l dan Perairan Teluk Awur sebesar 0,001-0,157 mg/l. Kandungan logam berat $\mathrm{Pb}$ sedimen di Perairan Kartini sebesar 2,424-3,463 mg/kg dan Perairan Teluk Awur sebesar 2,347-2,496 mg/kg. Kandungan logam berat Pb Lamun Enhalus acoroides pada akar di Perairan Kartini sebesar 0,918-1,854 mg/kg dan Perairan Teluk Awur sebesar 0,906-1,492 mg/kg. Kandungan logam berat $\mathrm{Pb}$ Lamun Enhalus acoroides pada daun di Perairan Kartini sebesar 0,764-1,458 mg/kg dan Perairan Teluk Awur sebesar 0,674-1,040 mg/kg.
\end{abstract}

Kata Kunci : Enhalus acoroides, Timbal (Pb), Pencemaran

\section{The Concentration of $\mathrm{Pb}$ in Enhalus acoroides LF. Royle 1839 (Angiosperms: Hydrocharitaceae) and Its Environment in the waters of Kartini and the Awur Bay, Jepara}

\begin{abstract}
Enhalus acoroides seagrass as a component of biodiversity that grows in the waters of Kartini and Teluk Awur. Activities in these waters include tourism, ports, manufacture, painting, welding, cleaning and traffic of fishing vessels to cause of accumulated heavy metals in the waters. Heavy metal $\mathrm{Pb}$ is a toxic and dangerous heavy metal, polluting material and tends to interfere with the survival of aquatic organisms. The purpose of this study was to determine and analyze the $\mathrm{Pb}$ heavy metal content in water, sediment and seagrass Enhalus acoroides (roots and leaves) in Kartini and Teluk Awur waters, Jepara, and to determine the level of pollution based on quality standards. This research uses descriptive method, while the location determination method uses purposive sampling method. The results showed that the heavy metal $\mathrm{Pb}$ water content in Kartini waters was $0.181 \mathrm{mg} / \mathrm{l}-0.316 \mathrm{mg} / \mathrm{l}$ and Teluk Awur waters was 0.01-0.157 mg/l. The heavy metal content of Pb sediment in Kartini waters is 2,424-3,463 mg/kg and Teluk Awur waters was 2,347$2,496 \mathrm{mg} / \mathrm{kg}$. The heavy metal content of $\mathrm{Pb}$ in Enhalus acoroides in the roots of Kartini waters was $0.918-1.854 \mathrm{mg} / \mathrm{kg}$ and Teluk Awur waters was $0.906-1.492 \mathrm{mg} / \mathrm{kg}$. Heavy metal content of Pb in Enhalus acoroides in leaves in Kartini waters was $0.764 \mathrm{mg} / \mathrm{kg}-1.458 \mathrm{mg} / \mathrm{kg}$ and Teluk Awur waters was $0.674-1.040 \mathrm{mg} / \mathrm{kg}$
\end{abstract}

Keywords: Enhalus acoroides, Lead (Pb), Pollution

\section{PENDAHULUAN}

Peningkatan pertumbuhan penduduk menimbulkan permasalahan lingkungan berupa pencemaran pada air, tanah, udara dan permasalahan sampah yang semakin meningkat dari hari ke hari (Herlambang, 2018). Permasalahan lingkungan perairan disebabkan oleh adanya sumber 
limbah dari industri, pemukiman, pelayaran, pertanian, limbah perkotaan, pertambangan dan perikanan budidaya. Limbah yang dibuang ke sungai mengalir ke perairan laut dan mengakibatkan pencemaran perairan yakni menurunnya kualitas air di perairan laut (Fransisca, 2011).

Pencemaran merupakan masuk atau dimasukkannya makhluk hidup, zat energi atau komponen lain ke dalam air atau udara sehingga kualitasnya menjadi kurang atau tidak dapat berfungsi sebagaimana mestinya (SK Menteri Kependudukan Lingkungan Hidup No. 02/MENKLH/1988).

Logam $\mathrm{Pb}$ adalah salah satu jenis logam berat yang dapat menyebabkan pencemaran perairan. Suatu perairan yang tercemar oleh $\mathrm{Pb}$ akan berdampak pada organisme perairan (Triadayani et al., 2018). Logam berat yang masuk ke sistem perairan, baik di sungai maupun lautan akan dipindahkan dari badan airnya melalui tiga proses yaitu pengendapan, adsorbsi dan absorbsi oleh organisme-organisme perairan. Pada saat buangan limbah masuk ke dalam perairan, selanjutnya akan terjadi proses pengendapan dalam sedimen khususnya terhadap materi-materi yang memiliki massa jenis besar (Erdayanti et al., 2015).

Salah satu cara untuk menentukan tingkat pencemaran di perairan laut adalah menggunakan makroalga. Lamun (seagrass) adalah tanaman air yang berbunga (antophyta) dan mempunyai kemampuan beradaptasi untuk hidup dan tumbuh di lingkungan laut. Lamun merupakan suatu penanda kapasitas akumulasi logam karena berinteraksi secara langsung dengan badan air dan air tanah (substrat) melalui daun dan akarnya untuk uptake ion-ion sehingga lamun dapat merefleksikan status kesehatan perairan secara keseluruhan (Ismarti et al., 2017).

Lamun Enhalus acoroides banyak terdapat pada seluruh perairan Indonesia. Enhalus acoroides sebagai salah satu komponen keanekaragaman hayati padang lamun, berkaitan dengan produktivitas primer yang berpengaruh terhadap rantai makanan. Tumbuhan ini dominan pada substrat dasar berpasir terdiri atas campuran pecahan karang yang telah mati dengan bioturbasi tinggi. Keberadaan untuk tumbuh biasanya terbatas pada bagian subtidal yang paling dangkal, mempunyai toleransi tinggi untuk berkembang (Takaendengan, 2010). Perakaran lamun yang kuat dapat berfungsi sebagai pengikat sedimen dan dapat menyerap nutrien yang terdapat di dalam substrat (Susetiono, 2004).

Tujuan penelitian ini ialah mengetahui dan menganalisis kandungan logam berat $\mathrm{Pb}$ pada air, sedimen dan lamun Enhalus acoroides (akar dan daun) yang terdapat di Perairan Kartini dan Teluk Awur, Jepara, serta mengetahui tingkat pencemarannya berdasarkan baku mutu.

\section{MATERI DAN METODE}

Materi yang digunakan pada penelitian ini adalah air, sedimen dan lamun Enhalus acoroides (akar dan daun) yang diambil dari Perairan Kartini dan Teluk Awur, Jepara (Gambar 1). Pada waktu yang bersamaan dilakukan pengukuran parameter perairan secara insitu meliputi suhu, salinitas, kandungan oksigen, $\mathrm{pH}$, kecerahan, kedalaman dan kecepatan arus. Metode penelitian yang digunakan berupa metode deskriptif, yakni mencari suatu interpretasi fakta yang bertujuan untuk membuat gambaran secara sistematis, faktual dan akurat mengenai fakta-fakta, sifat hubungan antara fenomena yang diselidiki secara nyata (Supriatini et al., 2016).

Metode dalam penelitian ini menggunakan metode Purposive sampling, yaitu metode sampling dengan pemilihan sekelompok subjek berdasarkan ciri atau sifat yang memiliki hubungan erat dengan ciri - ciri atau sifat yang sudah diketahui sebelumnya. Gambar 1. menunjukkan dua lokasi penelitian yakni Perairan Kartini (kotak merah) dan Teluk Awur (kotak kuning). Pengambilan sampel air laut dilakukan di setiap lokasi pada bulan Januari dan Februari menggunakan botol sampel ukuran 1,5 liter. Sampel air ditutup rapat dan dimasukkan ke dalam cool box.

Sampel sedimen diambil menggunakan sedimen core dengan diameter $10 \mathrm{~cm}$ dan panjang 30 $\mathrm{cm}$. Sampel diambil sebanyak 500 gram, kemudian dimasukkan ke dalam kantong plastik (Sari, 2017). Pengambilan sampel di setiap lokasi dilakukan dengan 3 kali pengulanga. Sampel lamun diambil yang lebih tua dengan ciri-ciri berupa warna daun lebih pekat dan tekstur lebih keras serta memiliki bagian-bagian yang lengkap (Supriatini et al., 2016). Selanjutnya lamun yang sudah diambil dimasukkan ke dalam plastik berlabel dan disimpan ke dalam coolbox. 

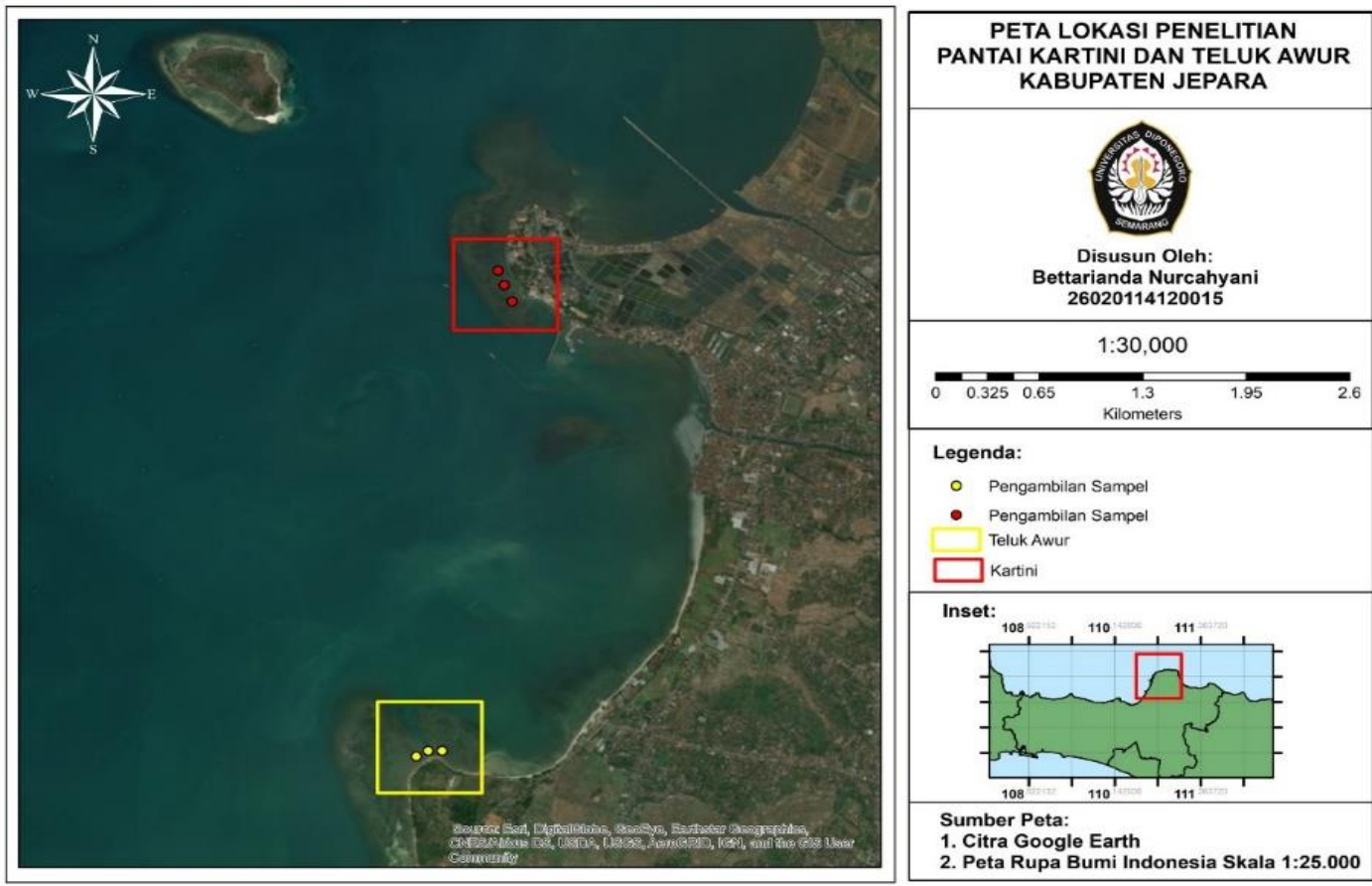

Gambar 1. Peta Lokasi Perairan Kartini dan Teluk Awur

\section{Pengukuran Kualitas Air}

Proses pengukuran data dilakukan secara insitu, yaitu langsung di lapangan pada waktu pengambilan sampel air dengan pengulangan sebanyak 3 kali. Suhu, $\mathrm{pH}$ dan oksigen terlarut (DO) diukur dengan menggunakan alat water quality checker, sedangkan untuk salinitas menggunakan refraktometer. Pengukuran kecerahan perairan dengan menggunakan secchi disk.

\section{Preparasi dan Analisis Kandungan Logam Berat}

Menurut Wulandari dan Sukesi (2013), preparasi sampel air laut dilakukan dengan cara mengambil sebanyak $30 \mathrm{ml}$ dan ditambahkan 10 tetes $\mathrm{HNO}_{3}$ ke dalam botol sampel yang telah diberi label, selanjutnya dilakukan analisis AAS di Laboratorium Kimia Analitik FMIPA Universitas Gajah Mada.

\section{Destruksi Sedimen}

Sampel sedimen yang sudah dikeringkan dalam oven pada suhu $105^{\circ} \mathrm{C}$ selama 12 jam kemudian ditimbang sebanyak 2 gram. Sampel dimasukkan ke dalam gelas beker $100 \mathrm{ml}$ dan ditambahkan larutan aquaregia (HNO3:HCL = 1:3) $20 \mathrm{ml}$ lalu didestruksi di atas hotplate dengan suhu $110^{\circ} \mathrm{C}$ sampai hampir kering, ditandai dengan hilangnya warna kuning pekat. Aquaregia berfungsi untuk merombak unsur senyawa yang tidak bisa diurai selain perak. Sampel didiamkan selama 15 menit dengan suhu kamar. Hasil destruksi dipindahkan ke dalam labu ukur berukuran $250 \mathrm{ml}$ kemudian ditambahkan akuades sampai tanda batas dan dilakukan analisis AAS di Laboratorium Kimia Analitik FMIPA Universitas Gajah Mada (Akbar, 2015).

\section{Preparasi Sampel (Akar dan Daun) Lamun Enhalus acoroides}

Preparasi sampel lamun Enhalus acoroides pada akar dan daun dilakukan dengan menggunakan metode destruksi basah. Metode tersebut merupakan perombakan sampel dengan asam - asam kuat baik tunggal maupun campuran, kemudian dioksidasi dengan menggunakan zat oksidator. Sampel yang telah siap dioven dengan suhu $100^{\circ}$ selama 45 menit. Sampel yang sudah kering ditimbang sebanyak \pm 5 gram, kemudian dimasukkan ke dalam gelas beaker $100 \mathrm{ml}$ untuk dilakukan destruksi basah dengan penambahan campuran asam $\mathrm{HNO}_{3} 65 \% \mathrm{H}_{2} \mathrm{O}_{2} 30 \%$ dengan perbandingan 3:1. $\mathrm{HNO}_{3}$ ditambahkan untuk memutuskan ikatan kompleks, sedangkan $\mathrm{H}_{2} \mathrm{O}_{2}$ untuk larutan pengoksidasi yang dapat menyempurnakan reaksi. Sampel dipanaskan di atas hotplate, 
lalu dituangkan sedikit demi sedikit $\mathrm{HNO}_{2}$ sebanyak $30 \mathrm{ml}$ dengan suhu $100^{\circ} \mathrm{C}$ dan dilakukan pengadukan seacara merata sampai tidak terbentuk gas, kemudian didinginkan selama 15 menit. Sampel dipanaskan kembali dengan penambahan $\mathrm{H}_{2} \mathrm{O}_{2}$ sebanyak $10 \mathrm{ml}$ hingga larutan menjadi jernih. Larutan hasil destruksi dipindahkan ke dalam labu ukur berukuran $50 \mathrm{ml}$ dan diencerkan $\mathrm{HNO}_{3} 1 \%$ hingga tanda batas. Larutan disaring menggunakan kertas saring whatman no. 42, kemudia dianalisis menggunakan AAS untuk mengetahui kandungan logam berat timbal $\mathrm{Pb}$ pada lamun (Wulandari dan Sukesi, 2013).

\section{HASIL DAN PEMBAHASAN}

Terdapat perbedaan kandungan logam berat Timbal $(\mathrm{Pb})$ dimana Perairan Kartini memiliki nilai yang lebih besar daripada Perairan Teluk Awur. Pada bulan Januari, kandungan logam berat $\mathrm{Pb}$ di Perairan Kartini sebesar 0,181 mg/L, sedangkan di Perairan Teluk Awur sebesar 0,01 mg/L. Terjadi peningkatan pada bulan Februari, dimana kandungan logam berat $\mathrm{Pb}$ di Perairan Kartini sebesar 0,316 mg/L, sedangkan di Perairan Teluk Awur sebesar 0,157 mg/L.

Perbedaan nilai kandungan logam berat $\mathrm{Pb}$ di kedua perairan tersebut disebabkan oleh beberapa hal, antara lain aktivitas pelabuhan, pembuatan kapal, pengecatan kapal, pengelasan kapal, pembersihan kapal dan lalu lintas kapal nelayan. Dahuri (2003) menambahkan bahwa tingginya aktivitas yang terjadi akan meningkatkan pencemaran, misalnya hasil buangan limbah timbal $(\mathrm{Pb})$ dari bahan bakar perahu. Kapal-kapal pariwisata yang menggunakan cat dengan kandungan logam berat timbal $(\mathrm{Pb})$ juga turut menjadi penyebabnya. Kandungan logam $\mathrm{Pb}$ yang lebih rendah di Perairan Teluk Awur disebabkan oleh rendahnya sumber pencemar yang ada dibandingkan dengan Perairan Kartini. Sumbernya antara lain aktivitas manusia, kapal nelayan, pembuangan limbah pertanian dan bengkel mobil atau motor. Pencemaran logam berat $\mathrm{Pb}$ di lingkungan perairan menimbulkan dampak negatif bagi kehidupan biota perairan dan manusia (Budiastuti et al., 2016).

Besarnya pencemaran kandungan logam berat $\mathrm{Pb}$ di kedua perairan tersebut disebabkan juga oleh tingginya curah hujan selama berlangsungnya penelitian. BMKG mencatat bahwa curah hujan pada bulan Januari dan Februari 2018 berturut-turut mencapai $576 \mathrm{~mm}$ dan $941 \mathrm{~mm}$. Tingginya curah hujan di bulan Februari diduga akibat meningkatnya buangan limbah perkotaan yang mengalir ke perairan laut. Arus dan pasang surut air laut memberikan pengaruh pada limbah yang masuk ke perairan tersebut. Hal ini diperkuat oleh Wardani et al. (2014), bahwa pergerakan logam berat pada perairan disebabkan oleh pasang surut dan arus sehingga terjadilah pengenceran. Pada waktu penelitian, kecepatan arus berkisar antara 0,4-0,5 m/s. Menurut Hoshika et al. (1991) kecepatan arus dapat mempengaruhi keberadaan logam berat yang berada

Tabel 1. Kandungan Logam Berat $\mathrm{Pb}$ pada Air, Sedimen dan Lamun Enhalus acoroides (Akar dan Daun) di Perairan Kartini dan Teluk Awur

\begin{tabular}{|c|c|c|c|c|c|c|c|}
\hline \multirow{3}{*}{ sampel } & \multicolumn{6}{|c|}{ Januari 2018} & \multirow{3}{*}{ Baku Mutu } \\
\hline & \multicolumn{3}{|c|}{ Kartini } & \multicolumn{3}{|c|}{ Teluk Awur } & \\
\hline & 1 & II & III & 1 & II & III & \\
\hline air (mg/L) & $\left.0,252^{*}\right)$ & $0,146^{*}$ & $\left.0,146^{*}\right)$ & $0,01^{*}$ & $0,01^{*}$ & $0,01^{*}$ & 0 \\
\hline rata - rata & \multicolumn{3}{|c|}{$0,181^{*} \pm 0,061$} & \multicolumn{3}{|c|}{$0,01^{*} \pm 0,000$} & 4,600 \\
\hline sedimen (mg/kg) & 2,797 & 2,22 & 2,256 & 2,616 & 2,169 & 2,256 & $201-256$ \\
\hline rata - rata & \multicolumn{3}{|c|}{$2,424 \pm 0,323$} & \multicolumn{3}{|c|}{$2,347 \pm 0,237$} & \\
\hline akar (mg/kg) & $\left.1,315^{*}\right)$ & $0,819^{*}$ & $\left.0,620^{*}\right)$ & $0,852^{*}$ & $0,837^{*}$ & $\left.1,028^{*}\right)$ & $0 ?$ \\
\hline rata - rata & \multicolumn{3}{|c|}{$0,918^{*} \pm 0,035$} & \multicolumn{3}{|c|}{$0,906^{*} \pm 0,107$} & , \\
\hline daun $(\mathrm{mg} / \mathrm{kg})$ & $\left.1,031^{*}\right)$ & $0,641^{*}$ & $\left.0,620^{*}\right)$ & $\left.0,783^{*}\right)$ & $0,617^{*}$ & $\left.0,621^{*}\right)$ & 02 \\
\hline rata - rata & \multicolumn{3}{|c|}{$\left.0,764^{*} \pm 0,231^{*}\right)$} & \multicolumn{3}{|c|}{$\left.0,674 \pm 0,09^{*}\right)$} & \\
\hline
\end{tabular}


Tabel 2. Kandungan Logam Berat $\mathrm{Pb}$ pada Air, Sedimen dan Lamun Enhalus acoroides (Akar dan Daun) di Perairan Kartini dan Teluk Awur

\begin{tabular}{|c|c|c|c|c|c|c|c|}
\hline \multirow{3}{*}{ Sampel } & \multicolumn{6}{|c|}{ Februari 2018} & \multirow{3}{*}{ Baku Mutu } \\
\hline & \multicolumn{3}{|c|}{ Kartini } & \multicolumn{3}{|c|}{ Teluk Awur } & \\
\hline & 1 & II & III & I & II & III & \\
\hline $\begin{array}{l}\text { air }(\mathrm{mg} / \mathrm{L} \\
\text { rata - rata }\end{array}$ & $\left.0,384^{*}\right)$ & $\begin{array}{c}\left.0,282^{*}\right) \\
0,316^{*} \pm 0,059\end{array}$ & $0,282^{*}$ & $\left.0,18^{*}\right)$ & $\begin{array}{c}\left.0,112^{*}\right) \\
0,157^{*} \pm 0,039\end{array}$ & $0,180^{*}$ & 0,008 \\
\hline $\begin{array}{c}\text { sedimen }(\mathrm{mg} / \mathrm{kg}) \\
\text { rata - rata }\end{array}$ & 3,954 & $\begin{array}{c}3,777 \\
3,463 \pm 0,703\end{array}$ & 2,657 & 2,854 & $\begin{array}{c}2,216 \\
2,496 \pm 0,326\end{array}$ & 2,419 & $20,1-25,6$ \\
\hline $\begin{array}{l}\text { akar }(\mathrm{mg} / \mathrm{kg}) \\
\text { rata - rata }\end{array}$ & $\left.2,657^{*}\right)$ & $\begin{array}{c}\left.1,944^{*}\right) \\
\left.1,854^{*}\right) \pm 0,085\end{array}$ & $\left.0,961^{*}\right)$ & $\left.1,877^{*}\right)$ & $\begin{array}{c}\left.1,298^{*}\right) \\
\left.1,492^{*}\right) \pm 0.333\end{array}$ & $1,300^{*}$ & 0,2 \\
\hline $\begin{array}{c}\text { daun }(\mathrm{mg} / \mathrm{kg}) \\
\text { rata - rata }\end{array}$ & $\left.1,537^{*}\right)$ & $\begin{array}{c}\left.1,469^{*}\right) \\
\left.1,458 \pm 0,08^{*}\right)\end{array}$ & $\left.1,368^{*}\right)$ & $\left.1,266^{*}\right)$ & $\begin{array}{c}\left.0,894^{*}\right) \\
\left.1,040 \pm 0,198^{*}\right)\end{array}$ & $0,961^{*}$ & 0,2 \\
\hline
\end{tabular}

Sumber nilai baku mutu:

Keputusan Menteri Lingkungan Hidup No. 51 (2004)

International Atomic Energi Agency SD-M-2/TM (1993)

Keputusan Dirjen Pengawasan Obat dan Makanan No. 03725/B/SK/VII/89

Tabel 3. Parameter Kualitas Perairan

\begin{tabular}{lccccc}
\hline \multirow{2}{*}{ Parameter } & \multicolumn{4}{c}{ Waktu } & \multirow{2}{*}{ Baku Mutu ${ }^{*}$ ) } \\
\cline { 2 - 5 } & \multicolumn{2}{c}{ Januari } & \multicolumn{2}{c}{ Februari } & \\
\cline { 2 - 5 } & $29-30$ & $30-31$ & $28-29$ & $29-30$ & $28-30$ \\
Suhu $\left({ }^{\circ} \mathrm{C}\right)$ & $29-30$ & $30-31$ & $27-28$ & $28-29$ & $28-35$ \\
Salinitas (\%o) & $7,7-7,9$ & $7,5-7,7$ & $7,9-80$ & $7,7-7,8$ & $>5$ \\
pH & $6-6,5$ & $6,6-7$ & $5,5-5,9$ & $5,7-6$ & $7-8,5$ \\
DO $(\mathrm{mg} / \mathrm{l})$ & $80-110$ & $80-85$ & $90-120$ & $80-85$ & \\
Kedalaman $(\mathrm{cm})$ & $70-80$ & $50-60$ & $60-70$ & $50-60$ & \\
Kecerahan $(\mathrm{cm})$ & 0,4 & 0,5 & 0,5 & 0,5 & \\
Arus $(\mathrm{m} / \mathrm{s})$ & 576 & 576 & 941 & 941 & \\
Curah Hujan $\left.{ }^{\mathrm{c}}\right)$ & \multicolumn{5}{c}{} \\
\hline
\end{tabular}

di perairan sehingga mengalami pengenceran dan menyebabkan logam berat yang terlarut dalam air dapat tersebar ke segala arah. Keberadaan logam berat $\mathrm{Pb}$ dapat mempengaruhi nilai kualitas perairan. Tingginya nilai $\mathrm{pH}$ dapat menurunkan kelarutan oksigen air dan meningkatkan toksisitas logam berat $\mathrm{Pb}$.

Kandungan logam berat Timbal $(\mathrm{Pb})$ di Perairan Kartini dan Perairan Teluk Awur telah melebihi baku mutu berdasarkan keputusan Menteri Lingkungan Hidup no. 51 tahun 2004. Menurut Sari et al. (2017), pencemaran logam berat di perairan dapat berdampak buruk terhadap kualitas air. Logam berat tersebut akan mengurangi penetrasi cahaya matahari yang masuk ke dalam badan air sehingga menyebabkan tingginya kekeruhan yang kemudian dapat menggangu proses metabolisme biota. Jika hal ini berlangsung terus-menerus maka dapat menyebabkan kematian pada biota tersebut.

\section{Kandungan Logam Berat Pb pada Sedimen di Perairan Kartini dan Teluk Awur}

Kandungan logam berat timbal $(\mathrm{Pb})$ yang terdapat dalam sedimen di Perairan Kartini pada Januari sebesar 2,424 mg/kg, sedangkan pada Februari meningkat menjadi $3,463 \mathrm{mg} / \mathrm{kg}$. Besarnya kandungan logam berat timbal $(\mathrm{Pb})$ yang terdapat dalam sedimen di Perairan Teluk Awur pada Januari sebesar 2,347 mg/kg, sedangkan pada Februari meningkat menjadi 2,496 $\mathrm{mg} / \mathrm{kg}$. Berdasarkan pengamatan, jenis sedimen di Perairan Kartini dan Teluk Awur ialah pasir berlanau. Penyebab adanya logam berat pada sedimen yaitu sifatnya yang mudah mengikat 
bahan organik, mengendap di dasar perairan lalu menyatu dengan sedimen. Kandungan logam berat dalam sedimen biasanya lebih tinggi dibandingkan dengan di air. Tingginya kandungan logam berat dalam sedimen disebabkan oleh lamanya proses pengendapan yang kemudian menyebabkan logam berat terakumulasi di dalam sedimen.

Pada awalnya, logam berat yang terlarut dalam air akan diadsorbsi oleh partikel halus kemudian diendapkan di dasar perairan oleh arus pasang surut. Logam berat yang ada di dalam perairan akan mengalami proses pengendapan dan terakumulasi dalam sedimen dan tubuh biota. Biota-biota laut memiliki kemampuan untuk menimbun logam (bioaccumulation) melalui rantai makanan sehingga terjadi metabolisme bahan berbahaya secara biologis, yang berdampak negatif pada organisme di perairan tersebut (Nasution dan Siska, 2012).

Kandungan logam berat $\mathrm{Pb}$ dalam sedimen di Perairan Kartini dan Teluk Awur relatif rendah dibandingkan dengan baku mutu yang ditetapkan oleh USA Geological Survey MAG-1 sehingga dapat disimpulkan bahwa sedimen di kedua perairan tersebut belum tercemar logam berat $\mathrm{Pb}$.

\section{Kandungan Logam Berat Pb pada Enhalus acoroides (Akar dan Daun) di Perairan Kartini dan Teluk Awur}

Terdapat peningkatan kandungan logam berat $\mathrm{Pb}$ pada akar lamun Enhalus acoroides baik di Perairan Kartini maupun Teluk Awur dari bulan Januari hingga Februari 2018. Pada Perairan Kartini (Januari) sebesar 0,918 ml/kg dan (Februari) sebesar 1,854 mg/kg. Sedangkan di perairan Teluk Awur (Januari) sebesar 0,906 mg/kg dan (Februari) sebesar 1,492 mg/kg.

Peningkatan kandungan logam berat $\mathrm{Pb}$ juga terjadi pada daun lamun Enhalus acoroides baik di perairan Kartini maupun Teluk Awur dari bulan Januari hingga Februari 2018. Pada perairan Kartini (Januari) sebesar $0,764 \mathrm{mg} / \mathrm{g}$ dan (Februari) sebesar 1,458 mg/g. Sedangkan di Perairan Teluk Awur (Januari) sebesar 0,674 mg/g dan (Februari) sebesar 1,040 mg/g.

Lamun Enhalus acoroides mampu menyerap logam berat melalui akar dan seluruh permukaan tubuhnya karena memiliki kutikula yang sangat tipis sehingga memudahkan penyerapan logam berat dari air (Prasad, 2008). Logam Pb yang diserap oleh akar akan ditranslokasikan ke batang menuju daun lamun, kemudian terakumulasi pada bagian daun.

Logam berat tersebut lalu masuk ke dalam sel dan berikatan dengan fitochelatin, yang selanjutnya membentuk komplek logam-khelat. Kemudian ditranspor ke vakuola untuk mengurangi efek toksisitasnya bagi tumbuhan. Proses ini berhubungan dengan luas permukaan bagian daun yang lebih besar sehingga memungkinkan semakin banyaknya dinding sel tanaman yang mengandung pektin dan karbohidrat yang berperan dalam proses penyerapan ion (Ismarti et al., 2017).

Rendah atau tingginya logam berat $\mathrm{Pb}$ di perairan dapat bersifat toksik yakni menghambat pertumbuhan lamun (Ambo-Rappe et al., 2011). Logam berat $\mathrm{Pb}$ yang masuk ke Perairan Kartini dan Teluk Awur baik di kolom perairan maupun di dasar perairan akan diserap oleh organisme perairan tersebut (Mirawati et al, 2016). Salah satu biota yang dapat menyerap logam berat ataupun senyawa lainnya adalah Lamun Enhalus acoroides. Tingginya serapan unsur hara yang diserap oleh bagian akar akan ditransportasikan melalui jaringan pengangkut (xylem dan floem). Kemudian disalurkan menuju daun yang diakumulasi pada vakuola (Heryanti et al., 2012). Hal ini dipengaruhi juga oleh pertambahan umur lamun dan keberadaan peptin yang terdapat pada daun lamun. Sehingga meningkatkan kemampuannya dalam menyerap logam berat (Kuo, 1998).

\section{KESIMPULAN}

Kandungan logam berat $\mathrm{Pb}$ pada Perairan Kartini dan Teluk Awur telah melampaui batas baku mutu menurut Kep Men LH NO.31. Kandungan logam berat Pb pada sedimen di Perairan Kartini dan Teluk Awur pada bulan Januari maupun Februari 2018 masih di bawah baku mutu menurut USA Geological Survey MAG-1 (1993). Kandungan logam berat Pb pada lamun Enhalus acoroides (akar dan daun) di Perairan Kartini dan Teluk Awur pada bulan Januari maupun Februari 2018 telah melampaui baku mutu menurut Keputusan Dirjen Pengawasan Obat dan Makanan No. 03725/B/SK/VII/89. 


\section{DAFTAR PUSTAKA}

Akbar, Syarifuddin, L. \& Maming. 2015. Analisis Logam Berat Timbal (Pb) dan Kadmium (Cd) Pada Akar, Kulit Batang, Daun Mangrove (Avicennia marina) dan Sedimen, Tanjung Bunga Makassar. Universitas Hasanuddin.

Ambo, R.R., Lajus, D.L., \& Schreider, M.J. 2011. Dampak Logam Berat terhadap Pertumbuhan dan Daun Asimetri Lamun Halophila Ovalis. Jurnal Kimia Lingkungan dan Ekotoksikologi, 3(6):149-159

Budiastuti, P., Raharjo, M. \& Dewanti, N.A.Y. 2016. Analisis Pencemaran Logam Berat Timbal di Badan Sungai Babon Kecamatan Genuk Semarang. Jurnal Kesehatan Masyarakat. 4(5):119118.

Erdayanti, P., Hanifah, T.A., \& Anita, S. 2015. Analisis Kandungan Logam Timbal pada Sayur Kangkung dan Bayam di Jalan Kartama Pekanbaru Secara Spektrofotometeri Serapan Atom. Jurnal Online Mahasiswa Fakultas Matematika dan IImu Pengetahuan Alam Universitas Riau, 2(1):75-82.

Fransisca, A. 2011. Tingkat Pencemaran Perairan Ditinjau dari Pemanfaatan Ruang di Wilayah Pesisir Kota Cilegon. Jurnal Perencanaan Wilayah dan Kota, 22(2):145-160

Haryati, M. 2012. Kemampuan Tanaman Genjer (Limnocharis Flava (L.) Buch.) Menyerap Logam Berat Timbal $(\mathrm{Pb})$ Limbah Cair Kertas pada Biomassa dan Waktu Pemaparan yang Berbeda. Lentera Bio, 1(3):131-138.

Herlambang, A. 2018. Pencemaran Air dan Strategi Penggulangannya. Jurnal Air Indonesia, 2(1).

Hoshika, A., Shiozawa, T., Kawana, K. \& Tanimoto, T. 1991. Heavy Metal Pollution in Sediment From the Seto Island, Sea Japan. Marine Pollution Bulletin, 23:101-105.

Ismarti, I., Ramses, R., Amelia, F., \& Suheryanto, S. 2017. Kandungan Tembaga (Cu) dan Timbal $(\mathrm{Pb})$ pada Lamun Enhalus accoroides dari Perairan Batam, Kepulauan Riau, Indonesia. DEPIK Jurnal IImu-IImu Perairan, Pesisir dan Perikanan, 6(1):23-30

Kuo, J. \& C. den Hartog. 2006. Seagrass Morphology, Anatomy, and Ultrastructure. in A.W.D. Larkum, R.J. Orth dan C.M. Duarte (ed). Seagrasses: Biology, Ecology and Conservation. Springer. Dordrecht. Netherlands, pp.51- 87

Mirawati, F., Supriyantini, E. \& Azizah, R. 2016. Kandungan Logam Berat Timbal (Pb) Pada Air, Sedimen, dan Kerang Hijau (Perna viridis) di Perairan Trimulyo dan Mangunharjo Semarang. Buletin Oseanografi Marina, 5(2):121-126.

Nasution, S., \& Siska, M. 2012. Kandungan Logam Berat Timbal (Pb) pada Sedimen dan Siput Strombus Canarium di Perairan Pantai Pulau Bintan. Jurnal IImu Lingkungan, 5(02):82-93

Prasad, M.N.V. 2008. Aquatic Plants for Phytotechnology. University of Hyderabad Press, $53 \mathrm{hlm}$.

Sari, A., Hidayat, D. \& Juliasih, N.L.G.R. 2017. Kajian Kandungan Logam Berat Kromium (Cr) Dan Mangan (Mn) Pada Ikan Teri Kering (Stolephorus Sp.) Di Pesisir Teluk Lampung Secara Spektrofotometri Serapan Atom. Analit 2(2):1-8.

Supriatini, E., Sedjati, S. \& Nurfadhli, Z. 2016. Akumulasi logam berat Zn (seng) pada lamun Enhalus acoroides dan Thalassia hemprichii di Perairan Pantai Kartini Jepara. Buletin Oseanografi Marina, 5(1):14-20.

Susetiono. 2004. Lamun dan Fauna Teluk Kuta, Pulau Lombok. Pusat Penelitian Oseanografi-LIPI: $99 \mathrm{hlm}$.

Takaendengan, K \& Muhammad H. A. 2010. Struktur Komunitas Lamun Di Pulau Talise, Sulawesi Utara. Oseanologi dan limnology di Indonesia, 36(1):85-95.

Triadayani, A.E., Aryawaty, R., \& Diansyah, G. 2010. Pengaruh Logam Timbal (Pb) Terhadap Jaringan Hati Ikan Kerapu Bebek (Cromileptes altivelis). Maspari Journal, 1(1):42-47. 
Wardani, D.A.K., Dewi, N.K., Utami, N.R. 2014. Akumulasi logam berat timbal (Pb) pada daging kerang hijau (Perna viridis) di muara Sungai Banjir Kanal Barat Semarang. Unnes J. Life Sci. $3(1): 1-8$.

Wulandari, E.A. \& Sukesi. 2013. Preparasi Penentuan Kadar Logam Pb, Cd, dan Cu dalam Nugget Ayam Rumput Laut Merah (Eucheuma cottonii). Jurnal Sains dan Seni ITS, 2(2):15-16. 